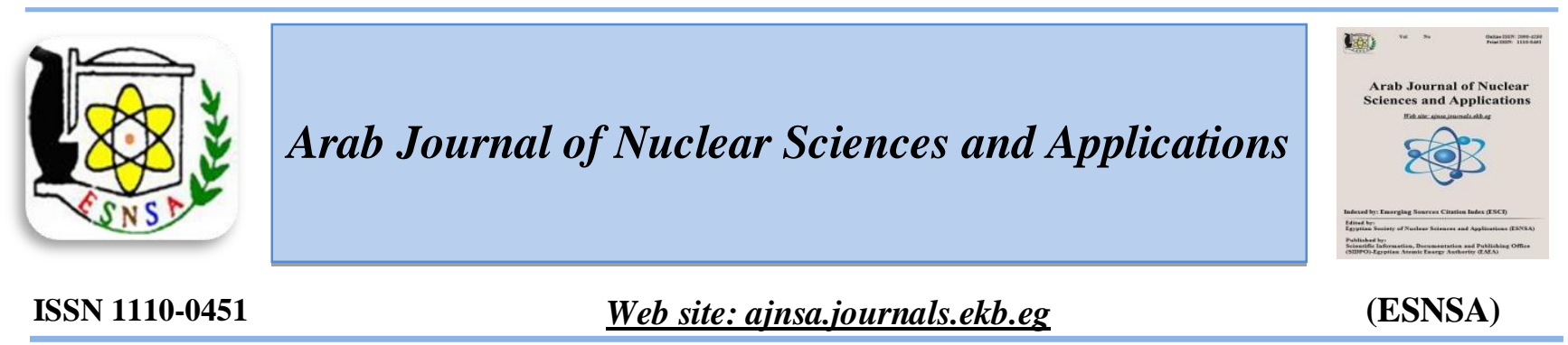

\title{
Kinetic and Thermodynamic Studies on Uranium Ions Recovery Using Magnetite- Dowex 50WX8 composite
}

\author{
L.A. Yousef \\ Nuclear Materials Authority, Cairo, Egypt
}

\begin{abstract}
Received 17 ${ }^{\text {th }}$ Jan 2019 Batch Experiments on synthesized "Magnetite-Dowex 50WX8" composite were conducted to Accepted $13^{\text {th }}$ Feb 2019 characterize its capability of uranium adsorption. The effect of pH, contact time, composite dose, initial uranium concentration and temperature on uranium adsorption rate was investigated to optimize the operation conditions of the synthesized composite. Thermodynamic and kinetic parameters have been studied. The maximum sorption capacity from Langmuir reached $200 \mathrm{mg} / \mathrm{g}$ at room temperature, $\mathrm{pH} \mathrm{4,}$ $25 \mathrm{mg}$ of composite and $30 \mathrm{~min}$. contact time. Uranium adsorption kinetics is well fitted to pseudo second order kinetic model at $500 \mathrm{mg} / \mathrm{L}$ uranium concentration. The change in the thermodynamic parameters ( $\Delta \mathrm{G}, \Delta \mathrm{H}$ and $\Delta \mathrm{S}$ ) indicates that the adsorption process is a spontaneous exothermic random process. Loaded hexavalent uranium ions were stripped from the loaded composite using $0.25 \mathrm{M}$ nitric acid. Optimum conditions were applied to purify the dissolved uranium content from a leaching solution of a granite sample from El-Missikat area, Central Eastern Desert, Egypt.
\end{abstract}

Keywords: Magnetite-Dowex 50WX8, Ion-exchange, Uranium, Thermodynamics, Kinetics

\section{Introduction}

Uranium is the conventional nuclear fuel used for nuclear power plants for peaceful applications. The growing demand of uranium supply is due to its prospective features [1]. Uranium milling processes have resulted in progressive exploration and development of advanced techniques to produce massive uranium concentrates worldwide [2-4]. Various techniques involved the recovery and separation of uranium out leaching solutions, including direct precipitation, solvent extraction, chromatographic separation, ion-exchange techniques, membrane dialysis, solid-liquid extraction, filtration, composite-in-pulp, biosorption and electro-deposition [5-27]. Most of such methods face technical and financial obstacles related to selectivity and duration of separation process and safety measures while dealing with hazardous materials applied in large quantities. Ion-exchange separation is considered one of the most reliable methods to remove trace levels of ions, due to its cost-effectiveness, simplicity and versatile nature [28, 29]. Adsorption processes, especially ion-exchange techniques are applied commercially for isolation, preconcentration and recovery of uranium ions from its solutions using specific composites. Among these composites; Amberlite IRA (100 mesh), Dowex-1X8 [30]. Amberlite IRA 402 is commonly used for uranium adsorption from sulfate solutions [31]. Adsorption of uranium onto Amberlite CG-400 composite is applicable from phosphate media [32]. Several studies covered the nature of uranium (VI) separation by Amberlite IRA-910 as well as Amberlite IR-118H [33, 34]. Uranium can also be recovered from acidic leach liquor using Ambersep 920U $\mathrm{SO}_{4}$ composite [35].

Corresponding author: drlamiayousef_77@live.com

DOI: 10.21608 /ajnsa.2019.7325.1171

(C) Scientific Information, Documentation and Publishing Office (SIDPO)-EAEA 
Different natural materials such as clays, seaweed and biomass, as well as synthetic materials including activated carbon, composites, and mesoporous silica have been used to adsorb heavy metals [36]. Uranium removal by chelating composites is a promising technique that has been reported in many studies [37, 38]. The only drawback of ion-exchange techniques is its high cost and the requirements for advanced pretreatment systems. Recently, the application of iron oxides, especially magnetite nano-particles for heavy metals removal have been investigated, due to their minute size, magnetic separation and the ease of synthesis, coating and modification [3942]. However, magnetite nano-particles lose some of their magnetic properties due to aerial oxidation. Coating with inorganic shell such as silica and carbon was studied and was found to be capable of improving the chemical stability of magnetite nano-particles [43 - 45]. The use of magnetic composites in separation of heavy metals has been studied exclusively [46].

Early in 1995, magnetic ion-exchange composites were applied for the removal of organic matter [43]. Magnetic composites are easily isolated from solutions through application of an external magnetic field and are characterized by their high uptake capacity compared to free magnetic nanoparticles [44].

It was found that in sulfate leach liquors of $\mathrm{El}$ Missikat ores that Mo in its hexavalent state is similar to the hexavalent $\mathrm{U}$ and thus may form anionic complexes of the type $\mathrm{MoO}_{2}\left(\mathrm{SO}_{4}\right)_{n}{ }^{2-2 n}$. These can be adsorbed more strongly than uranium complexes and are not removed by normal elution process, which leads to the reduction of uranium capacity of the composite [47]. El-Missikat granite ore materials have been subjected to direct agitation leaching technique using diluted sulfuric acid beside sulsatization roasting, as well as pressurized alkaline leaching processes. Alkaline leached proved to be more effective in recovering most of uranium content (95.6\%), while the leaching extent of Mo was $93.1 \%$. However, the recovery of both $\mathrm{U}$ and Mo would be greatly facilitated when using this technique [48].

In this work, magnetite-Dowex 50WX8 composite was prepared using co-precipitation method. The prepared composite has been synthesized, characterized and tested to calculate adsorption kinetics and thermodynamic parameters of uranium adsorption from El-Missikat leach liquor.

\section{Experimental}

Dowex 50WX8 characteristics

A strong acid cation-exchange Dowex 50WX8 composite of Dow Co. was used in this work to synthesize magnetite-Dowex 50WX8 composite. The used composite contains exchangeable $\mathrm{H}^{+}$ ions. The porous nature of the polymeric structure provides the composite its superior adsorption capacity of large ions. It retains its activity from sulfonic groups. Dowex 50WX8 has excellent regeneration efficiency due to cross-linked polystyrene, excellent physical stability and high adsorption capacity. The structure of Dowex 50WX8 provides an excellent stability towards organic as well as inorganic decomposition. The adsorption capacity of the applied composite was found to be $1.7 \mathrm{meq} / \mathrm{ml}$. It means that, the uptake capacity of Dowex 50W-X8 for uranium (VI) adsorption is $67.43 \mathrm{mg} / \mathrm{g}$.

Synthesis of (Magnetite-Dowex 50WX8) composite One gram of Dowex 50W-X8 composite was put in beaker containing one gram of each of $\mathrm{Fe}_{2}\left(\mathrm{SO}_{4}\right)_{3} .5 \mathrm{H}_{2} \mathrm{O}, \mathrm{FeSO}_{4} 7 \mathrm{H}_{2} \mathrm{O}$ and Ferric oxide. The mixture of Dowex and iron salts was diluted to $300 \mathrm{ml}$ with distilled water, heated to $80{ }^{\circ} \mathrm{C}$ while stirred at $200 \mathrm{rpm}$ for 3 hours. After cooling, ammonium hydroxide solution was added to precipitate iron at $\mathrm{pH}$ 10-12 [49]. The solution was filtered and washed with distilled water. The obtained precipitate was dried at $80^{\circ} \mathrm{C}$. The prepared magnetite-Dowex 50WX8 composite was synthesized at optimum conditions, except for iron sulfate salts that have been used instead of iron chloride ones.

Characterization of adsorbent

Fourier transform infrared spectrometer characterization

Fourier-transform infrared spectroscopy (FTIR) is a technique used to identify molecular and functional groups [50]. FTIR model "Thermo Scientific Nicolet IS10" instrument via KBR pressed disc method, in a range starting from 400 to $4000 \mathrm{~cm}^{-1}$ wave number was used. The obtained Data of Dowex 50WX8 as well as the prepared magnetite-Dowex 50WX8 composite are shown on (Fig.1a and 1b). From which, the peak is observed at $3501 \mathrm{~cm}^{-1}$ corresponding to $\mathrm{O}-\mathrm{H}$ stretching. The $\mathrm{C}-\mathrm{H}$ stretching in alkene appeared at $2932 \mathrm{~cm}^{-1}$, while the band at $1643 \mathrm{~cm}^{-1}$ correspond to $\mathrm{C}=\mathrm{C}$ of alkene. The bands at 1496, 1452, $1413 \mathrm{~cm}^{-1}$ are related to $\mathrm{C}=\mathrm{C}$ ring stretching. The peaks obtained 
at 1185 and $1126 \mathrm{~cm}^{-1}$ stand for $\mathrm{S}-\mathrm{OH}$ and $\mathrm{S}(=\mathrm{O})_{2}$ respectively. The two bands at 1039 and $1006 \mathrm{~cm}^{-}$ ${ }^{1}$ are attributed to $\mathrm{S}-\mathrm{O}-\mathrm{C}$ stretching. The $\mathrm{C}=\mathrm{C}$ in alkene appeared at $836 \mathrm{~cm}^{-1}$. The band at $677 \mathrm{~cm}^{-1}$ is due to C-S stretching band. Finally, the peaks at 580 and $621 \mathrm{~cm}^{-1}$ are related to atactic polystyrene Fig. (1a).

On the other hand, the prepared (magnetite-Dowex 50WX8) composite showed two bands at 532 and $455 \mathrm{~cm}^{-1}$ that are attributed to $\mathrm{Fe}-\mathrm{O}$ bending. The $\mathrm{O}-\mathrm{H}$ band is shifted to $3336 \mathrm{~cm}^{-1}$. The band at $2932 \mathrm{~cm}^{-1}$ disappeared, indicating the formation of magnetite composite. Absorbance bands for most groups have been shifted for the prepared magnetite composite due to the precipitation of iron on Dowex50WX8. This attitude confirms the coordination bonding of Fe to the Sulfur atom of the strong cation exchange Dowex 50WX8 Fig. (1b).

\section{Environmental scanning electron microscope "ESEM"}

ESEM has become a powerful device for material examination [51]. Environmental scanning electron microscope Philips XL30 ESEM FEG has been used at the working temperature of the emitter $1800^{\circ} \mathrm{K}, 25-30 \mathrm{KV}$ accelerating voltage, $1-2 \mathrm{~mm}$ beam diameter and 60-120s counting time, minimum detectable weight concentrations ranging from 0.1 to $1 \mathrm{wt} \%$, while the realized precision is below1\%.

The image of the surface of magnetite-Dowex 50WX8 composite is shown in Fig. (2). After iron precipitation, homogeneous brilliant spots are observed on the composite beads that are free of agglomeration. The size of the composite is $50 \mathrm{~nm}$

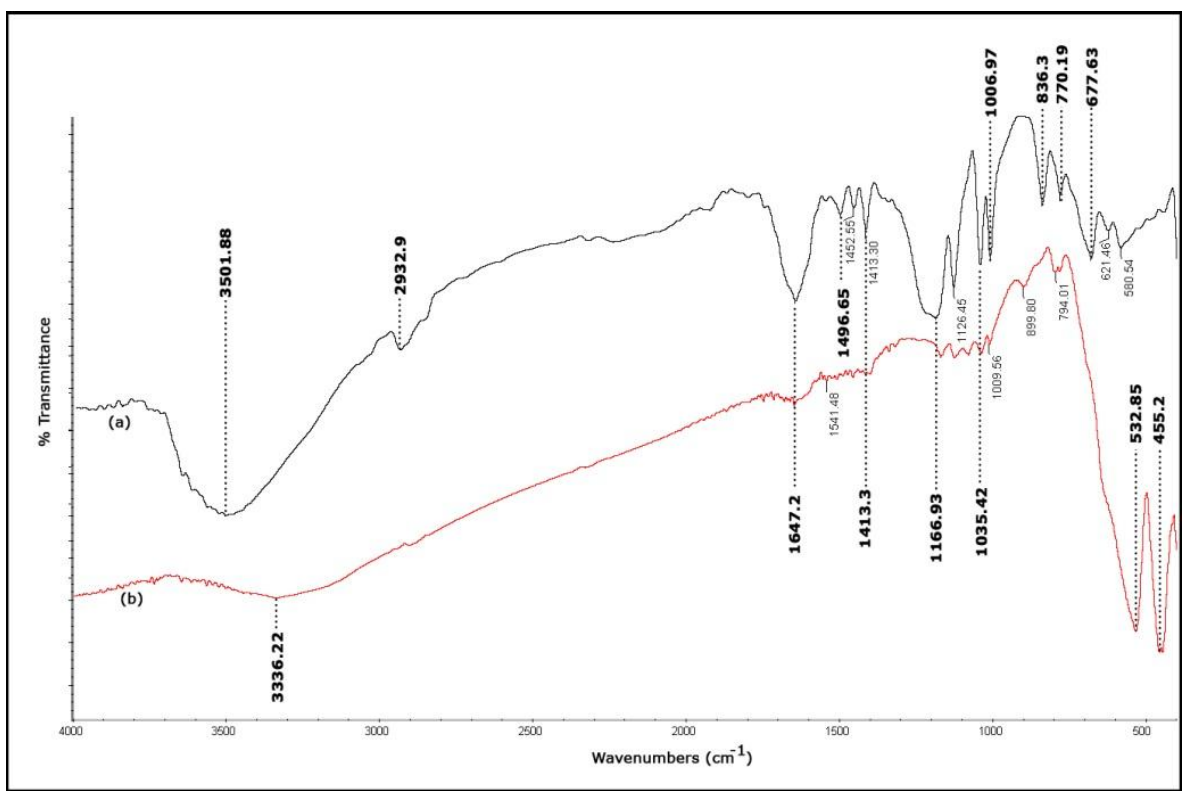

Fig. (1): FTIR chart of the Dowex 50 WX8 (a) and prepared (magnetite-Dowex 50WX8) composite (b)

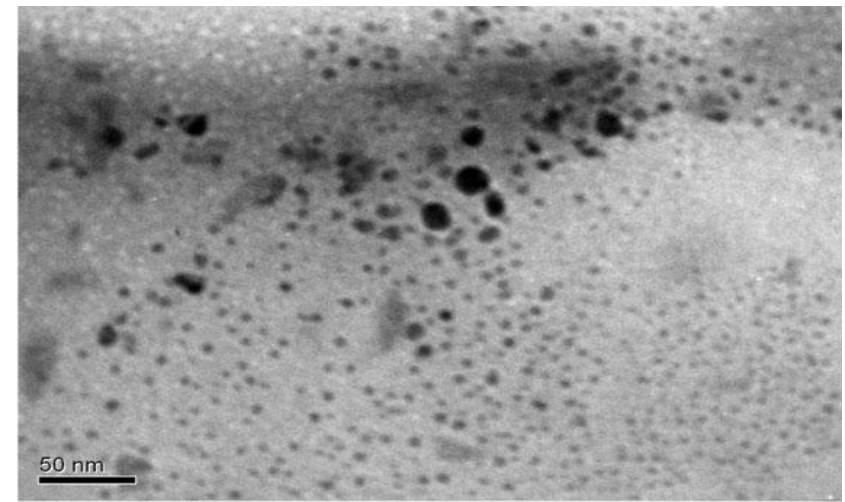

Fig. (2): SEM of prepared (magnetite-Dowex 50WX8) composite 


\section{Analytical procedures}

Uranium was measured volumetrically by oxidation-reduction titration $\mathrm{Vs}\left[\mathrm{NH}_{4}\right] \mathrm{VO}_{3}$ [52]. Data was collected and compared to spectrophotometric analysis of $U$ by Metertech Inc (SP-8001) using Arsenazo III method at $\lambda 655 \mathrm{~nm}$ [53]. Major oxides such as silica, alumina and titanium oxides were quantified spectrophotometrically via standard analytical techniques while sodium and potassium oxides were measured using flame photometer. $\mathrm{Fe}_{2} \mathrm{O}_{3}{ }^{\mathrm{T}}$, $\mathrm{CaO}$ and $\mathrm{MgO}$ have been determined by volumetric titration [54]. Each sample was analyzed in triplicate. Trace elements were analyzed using ICP-MS at Henri Poincare University laboratories, Nancy, France [55]. Quality control of the analyses was confirmed using international geostandards

\section{Analytical procedures}

Uranium was measured volumetrically by oxidation-reduction titration $\mathrm{Vs}\left[\mathrm{NH}_{4}\right] \mathrm{VO}_{3}$ [52]. Data was collected and compared to spectrophotometric analysis of $U$ by Metertech Inc (SP-8001) using Arsenazo III method at $\lambda 655 \mathrm{~nm}$ [53]. Major oxides such as silica, alumina and titanium oxides were quantified spectrophotometrically via standard analytical techniques while sodium and potassium oxides were measured using flame photometer. $\mathrm{Fe}_{2} \mathrm{O}_{3}{ }^{\mathrm{T}}$, $\mathrm{CaO}$ and $\mathrm{MgO}$ have been determined by volumetric titration [54]. Each sample was analyzed in triplicate. Trace elements were analyzed using ICP-MS at Henri Poincare University laboratories, Nancy, France [55]. Quality control of the analyses was confirmed using international geostandards.

\section{El-Missikat sample}

El Missikat uranium prospect lies at midway along Qena-Safaga road in the Central Eastern Desert of Egypt Fig. (3). El Missikat prospect, as a wide shear zone striking ENE-WSW direction, comprises generations of silica veins crosscut in a wide younger granite pluton Fig. (4). Some of these silica injections are associated with uranium and other valuable minerals.

\section{Preparation of El-Missikat sample}

The studied El-Missikat sample was attacked using mixture of acids $\mathrm{HF}, \mathrm{HNO}_{3}, \mathrm{HClO}_{4}$ and $\mathrm{HCl}$, to quantify major oxides inside the samples collected from El-Missikat shear zone, Central Eastern Desert, Egypt Table (1). The analyses of trace elements (ppm) were determined and shown in Table (2).

\section{Preparation of El-Missikat leach liquor}

To prepare the leach liquor, El-Missikat samples were leached at optimum conditions to ensure the maximum uranium leaching efficiency $(83.3 \%)$ with minimum contamination of unwanted species. Optimum conditions are -200 mesh grinding size, $0.2 \mathrm{M} \mathrm{HNO}$, 3:1 Liquid: solid ratio, $200 \mathrm{rpm}$ agitation speed for 3 hours at $60{ }^{\circ} \mathrm{C}$. After cooling, the solution was filtered then, uranium was measured in leach liquor.

The obtained leach liquor uranium concentration was found to be $2000 \mathrm{mg} / \mathrm{L}$, while the concentration of uranium in El-Missikat ore sample was $2400 \mathrm{mg} / \mathrm{L}$ Table (1).

\section{Adsorption studies}

Batch adsorption experiments were performed by agitation of the pregnant solution together with a certain amount of composite for a certain time at a definite temperature till equilibrium was achieved. In order to estimate the best conditions for uranium adsorption from solution using (magnetiteDowex50WX8) composite, the mixture was mechanically stirred at $200 \mathrm{rpm}$ at variable $\mathrm{pH}$ values from $\mathrm{pH} 1$ to $\mathrm{pH} 7$, while changing the composite amount and uranium concentrations along from 50 to $1000 \mathrm{ppm}$ at different agitation time intervals from 5 to 120 minutes and variable degrees of temperature. The composite was filtered off and uranium was measured in the filtrate each time. Adsorption capacity for uranium $\left(\mathrm{q}_{\mathrm{e}}, \mathrm{mg} / \mathrm{g}\right)$ as well as uranium adsorption efficiency $(\% \mathrm{E})$ and distribution coefficient $\left(\mathrm{K}_{\mathrm{d}}\right)$ were calculated from the mathematical relations:

$\mathrm{q}_{\mathrm{e}}=\left(\mathrm{C}_{\mathrm{o}}-\mathrm{C}_{\mathrm{e}}\right) \times \mathrm{v} / \mathrm{m}$

$\mathrm{E}(\%)=100\left(\mathrm{C}_{\mathrm{o}}-\mathrm{C}_{\mathrm{e}}\right) / \mathrm{C}_{\mathrm{o}}$

$\mathrm{K}_{\mathrm{d}}=\left[\left(\mathrm{C}_{\mathrm{o}}-\mathrm{C}_{\mathrm{e}}\right) / \mathrm{C}_{\mathrm{e}}\right] \times \mathrm{V} / \mathrm{m}$

Where; $\mathrm{C}_{\mathrm{o}}$ and $\mathrm{C}_{\mathrm{e}}$ are uranium concentrations initially and at equilibrium state respectively measured in ppm, $\mathrm{V}$ is the aqueous solution volume, while $m$ is the mass of the dry composite in grams. 


\section{Elution studies}

Different agents have been tested for such purpose; $\mathrm{HNO}_{3}, \mathrm{HCl}$ and $\mathrm{H}_{2} \mathrm{SO}_{4}$ acids were used to strip uranium ions from the loaded composite. In each experiment, $25 \mathrm{mg}$ of the loaded composite were shacked with $10 \mathrm{ml}$ of each eluting agent at variable concentrations for 30 minutes at room temperature.

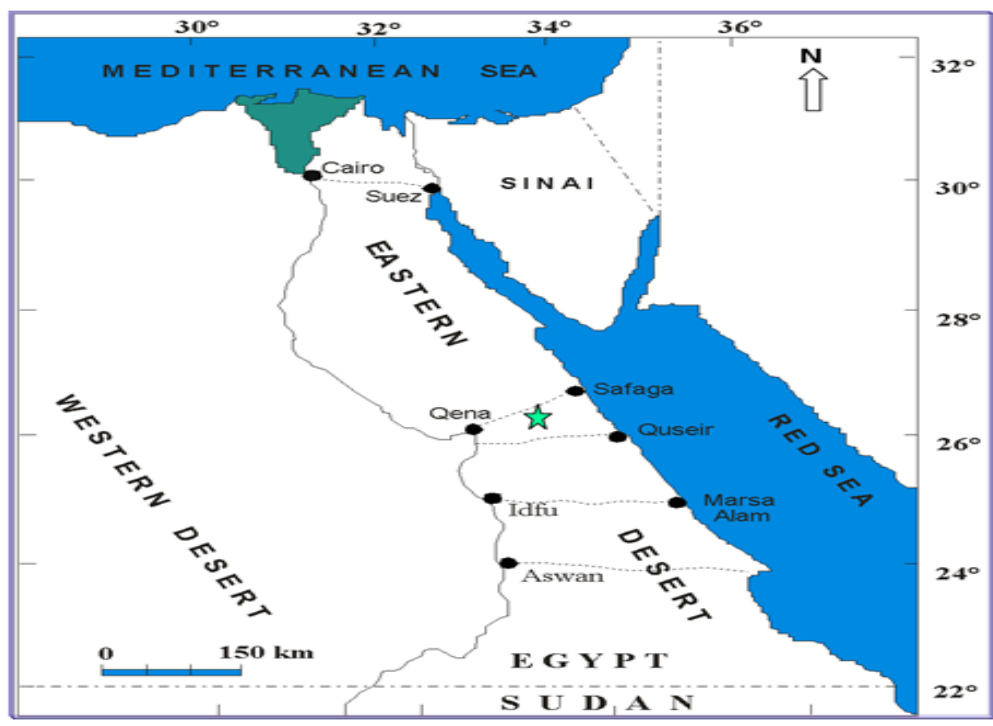

Fig. (3): Location map of El-Missikat granite, Central Eastern Desert, Egypt

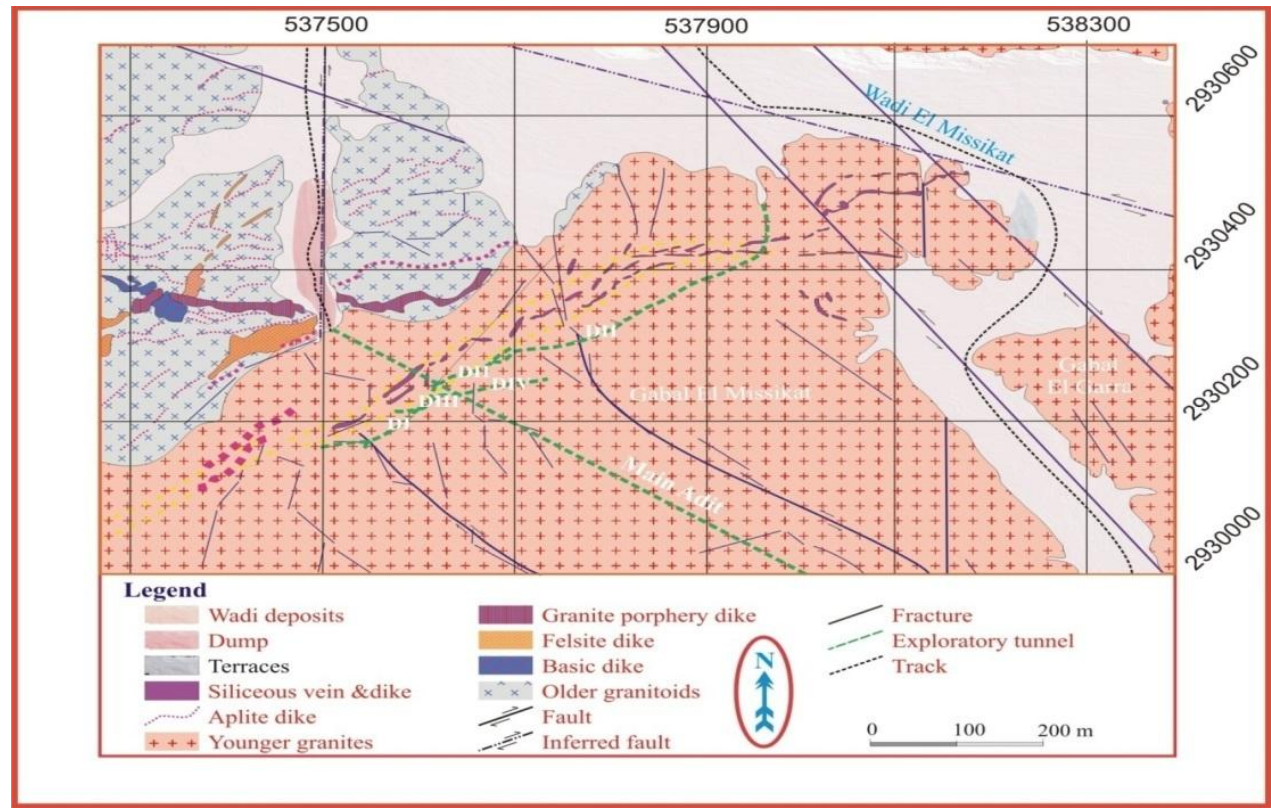

Fig. (4): El Missikat granite, shear zone and the Silica veins, after [56] 
Table (1): Chemical composition of major oxide (wt \%) and uranium concentration (mg/L)

\begin{tabular}{|c|c|}
\hline Major oxides & Wt \% \\
\hline $\mathrm{SiO}_{2}$ & 92.7 \\
\hline $\mathrm{Al}_{2} \mathbf{O}_{3}$ & 2.9 \\
\hline $\mathrm{TiO}_{2}$ & N.D* \\
\hline $\mathrm{Fe}_{2} \mathrm{O}_{3}{ }^{\mathrm{T}}$ & 0.67 \\
\hline $\mathrm{CaO}$ & 1.67 \\
\hline MgO & N.D* \\
\hline $\mathrm{Na}_{2} \mathrm{O}$ & N.D* \\
\hline $\mathbf{K}_{2} \mathbf{O}$ & N.D* \\
\hline $\mathbf{P}_{2} \mathbf{O}_{5}$ & N.D* \\
\hline L.O.I & 1.74 \\
\hline Total & 99.7 \\
\hline $\mathbf{U}$ & $2400(\mathrm{mg} / \mathrm{L})$ \\
\hline
\end{tabular}

$* \mathrm{~N} . \overline{\mathrm{D}}=$ not detected (under limit of detection)

Table (2): Trace elements content (ppm) using ICP-MS technique

\begin{tabular}{cc}
\hline Trace elements & $(\mathbf{p p m})$ \\
\hline Ba & 200 \\
$\mathbf{R b}$ & 4.75 \\
$\mathbf{S r}$ & 22.7 \\
$\mathbf{T a}$ & 21.4 \\
$\mathbf{N b}$ & 130 \\
$\mathbf{Z r}$ & 177 \\
$\mathbf{Y}$ & 157 \\
$\mathbf{T h}$ & 20.8 \\
$\mathbf{P b}$ & 1868 \\
$\mathbf{Z n}$ & 177 \\
$\mathbf{H f}$ & 12 \\
$\mathbf{N i}$ & 6 \\
Ga & 10.3 \\
Mo & 1570 \\
\hline
\end{tabular}




\section{Results and Discussion}

\section{pH of uranium solution}

The $\mathrm{pH}$ value of the uranium solution is so important for successful uranium adsorption by any composite. The $\mathrm{pH}$ value directly affects both the soluble aqueous uranium species present in solution of as well as the composition of active sites on the adsorbent surface [57]. The retention of uranium (VI) on prepared (magnetite Dowex 50WX8) composite was studied in $\mathrm{pH}$ range 1-7 using $10 \mathrm{ml}$ uranium solution conc. $500 \mathrm{ppm}$, 0.025 grams of composite and $200 \mathrm{rpm}$ agitation speed for 30 minutes. The obtained results indicated that uranium (VI) adsorption efficiency rises with $\mathrm{pH}$ range from 1 to 4 (adsorption efficiency $=95 \%$, and $\mathrm{qe}=190 \mathrm{mg} / \mathrm{g}$ ) and then, adsorption decreases with increasing $\mathrm{pH}$ till 7 (Fig. 5). The maximum sorption capacity for uranium ions was found to be at the $\mathrm{pH}$ value of 4 for the prepared (magnetite-Dowex 50WX8) composite. This may be attributed to the limitation of uranium adsorption below the $\mathrm{pH}$ value of 3 , due to the electrostatic repulsive forces between the prepared (magnetite-Dowex 50WX8) composite and metal ions, and the hindering of metal ions sorption on the surface $[58,59]$. At the $\mathrm{pH}$ value of 4 , the adsorption increases due to the enhanced ionization of sorption sites owing to the competition between uranium and $\mathrm{H}_{3} \mathrm{O}^{+}$. At $\mathrm{pH} 5$, most of the metal ions precipitate as hydroxides.

\section{Contact time}

The influence of varying contact time was monitored while fixing other conditions that affect uranium adsorption. The agitation time was varied from 5 to 120 minutes. It was found that the uranium adsorption efficiency on the prepared (magnetite-Dowex 50WX8) composite increased as time of agitation was increased Fig. (6). Adsorption nearly reached equilibrium after 30 minutes. Furthermore, there was no significant change in uranium adsorption by the studied composite in the next 60 minutes. Uranium uptake slowly increased from $79 \%$ at the first 5 minutes till $95 \%$ through 30 minutes (adsorption efficiency $=95 \%$, qe $=190 \mathrm{mg} / \mathrm{g}$ ). Beyond this time, no change in adsorption occurred; this revealed that equilibrium was reached.

\section{Uranium solution concentration}

A series of solutions, $10 \mathrm{ml}$ each, with different uranium concentration from 50 to $1000 \mathrm{ppm}$ were contacted with $25 \mathrm{mg}$ of composite at a $\mathrm{pH}$ value of 4 and $200 \mathrm{rpm}$ agitation speed for 30 minutes. Results obtained are presented in terms of adsorption efficiency and maximum uranium uptake $\left(\mathrm{q}_{\mathrm{e}}\right)$ in Fig. (7), which reveals that the adsorption of uranium on the prepared composite decreases from $(98-95 \%)$ with $(50-500 \mathrm{ppm})$ and drops to $50 \%$ with $1000 \mathrm{ppm}$ solution. A solution of initial uranium concentration of $500 \mathrm{ppm}$ was found to be suitable enough as it corresponds to an adsorption efficiency of $95 \%$ and $\mathrm{qe}=190 \mathrm{mg} / \mathrm{g}$ ).

\section{Temperature variance}

For testing this factor, adsorption efficiency was monitored at a temperature range from $25^{\circ} \mathrm{C}$ to $100^{\circ} \mathrm{C}$, while fixing all other variables; $500 \mathrm{ppm}$ uranium concentration, $\mathrm{pH} 4$ and $200 \mathrm{rpm}$ stirring speed for 30 minutes. The results are presented in Fig. (8) that shows that the efficiency of uranium adsorption by the studied composite decreases from $95 \%$ at $25^{\circ} \mathrm{C}$ to $50 \%$ at $100{ }^{\circ} \mathrm{C}$. It was concluded that the best temperature to perform uranium adsorption by the studied medium was room temperature, (adsorption efficiency $=95 \%$, $\mathrm{qe}=190 \mathrm{mg} / \mathrm{g}$ ).

\section{Composite dose}

The influence of composite dose has been investigated ranging from 10 to $250 \mathrm{mg}$ mixed with $10 \mathrm{ml}$ volume of uranium solution at optimum conditions of other factors. The results in Fig. (9) shows that the adsorption efficiency changed from $85 \%$ using only $10 \mathrm{mg}$ of composite till reaching 95\% using $25 \mathrm{mg}$ and then, remained constant with increasing composite dose. Therefore, the required composite dose to adsorb uranium (VI) was chosen to be $25 \mathrm{mg}$, (adsorption efficiency $=95 \%$, qe= $190 \mathrm{mg} / \mathrm{g}$ ). Increasing the adsorbent dose provides more available sorption sites and high surface area. It can be concluded that the composite gives a higher uranium adsorption using the prepared (magnetite-Dowex50WX8) composite.

\section{Desorption and regeneration of the prepared composite \\ Three eluting agents were tested to determine which offers the best elution efficiency. Different concentrations of the tested acids were prepared from $0.12 \mathrm{M}$ to $1.0 \mathrm{M}$. A volume of $10 \mathrm{ml}$ of the prepared eluent solution was allowed to contact with $25 \mathrm{mg}$ of the composite for 30 minutes. The results obtained in Table (3) clarify that desorption}


efficiency increased as acid concentration of the eluting solution increased. The best elution efficiency was found to be $99 \%$ with $50 \mathrm{ml}$ of $0.25 \mathrm{M} \mathrm{HNO}_{3}$ or $0.75 \mathrm{M} \mathrm{H}_{2} \mathrm{SO}_{4}$ and $85 \%$ with $1 \mathrm{M}$ $\mathrm{HCl}$ acid solution from $25 \mathrm{mg}$ loaded composite. The uranium loaded onto the prepared composite was dissolved using $0.25 \mathrm{M} \mathrm{HNO}_{3}$. The adsorptionelution process was repeated several times till adsorption efficiency was reduced to $85 \%$ and elution was reduced to $90 \%$ after ten cycles. This indicated the superior affinity of the prepared magnetite-Dowex 50WX8 composite for uranium recovery.
Stability of the prepared (magnetite-Dowex 50WX8) composite

A series of prepared $10 \mathrm{ml}$ of different $\mathrm{HNO}_{3}$ concentrations ranging from 0.1 to $3 \mathrm{M}$ were mixed with $25 \mathrm{mg}$ of the prepared composite at $200 \mathrm{rpm}$ for 30 minutes at room temperature. The prepared composite was separated and $\mathrm{Fe}$ content was measured in the filtrate. Iron dissolution was not detected by $0.1-0.6 \mathrm{M} \quad \mathrm{HNO}_{3}$. Beyond this concentration, iron dissolution increased from $0.035 \%$ by $0.7 \mathrm{M} \mathrm{HNO}_{3}$ to $5 \%$ by $3 \mathrm{M} \mathrm{HNO}_{3}$ Table (4). Accordingly, a recommended concentration of $\mathrm{HNO}_{3}$ in the range $0.1-0.6 \mathrm{M}$ was added to keep the stability of the prepared composite and to prevent unwanted dissolution of iron.

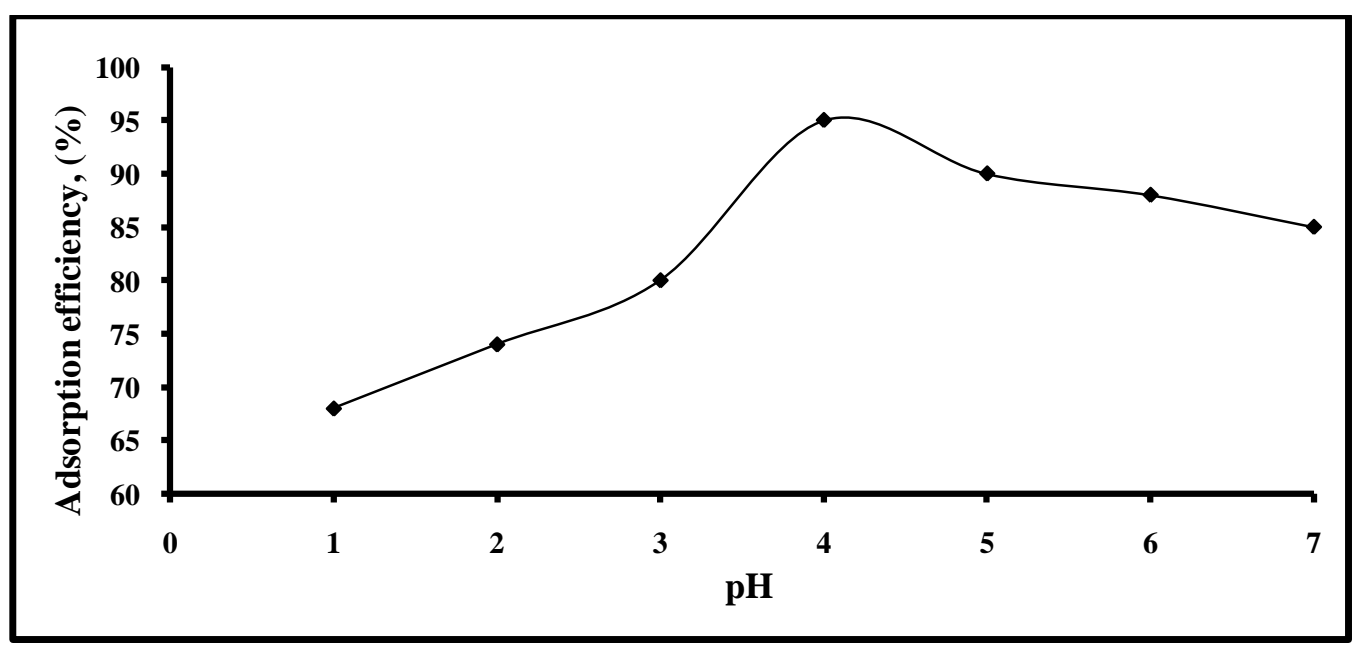

Fig. (5): Effect of pH on uranium adsorption efficiency using the prepared (magnetite- Dowex 50WX8) composite Adsorption conditions: 500 ppm uranium concentration, $30 \mathrm{~min}$. contact time, room temperature and $25 \mathrm{mg}$ composite dose

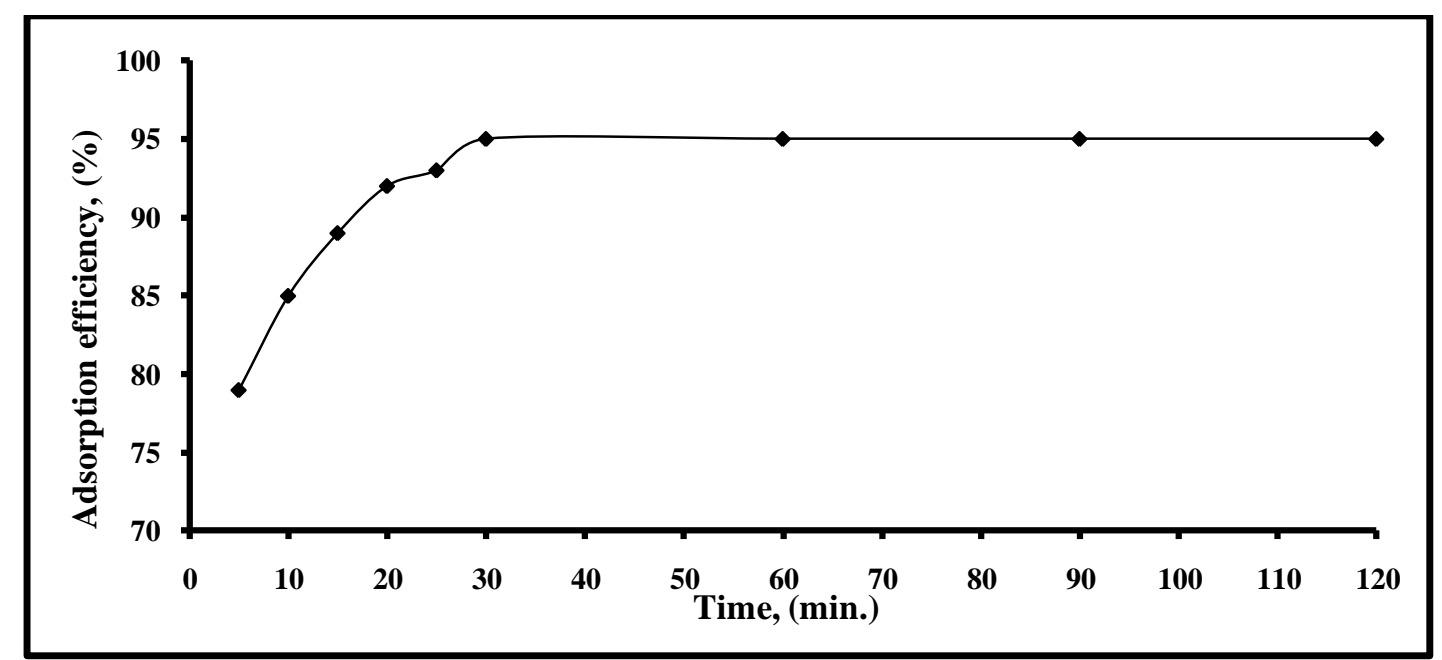

Fig. (6): Effect of contact time (min.) on uranium adsorption efficiency using the prepared (magnetite-Dowex 50WX8) composite

Adsorption conditions: 500 ppm uranium concentration, pH 4, room temperature and 25 mg composite dose. 


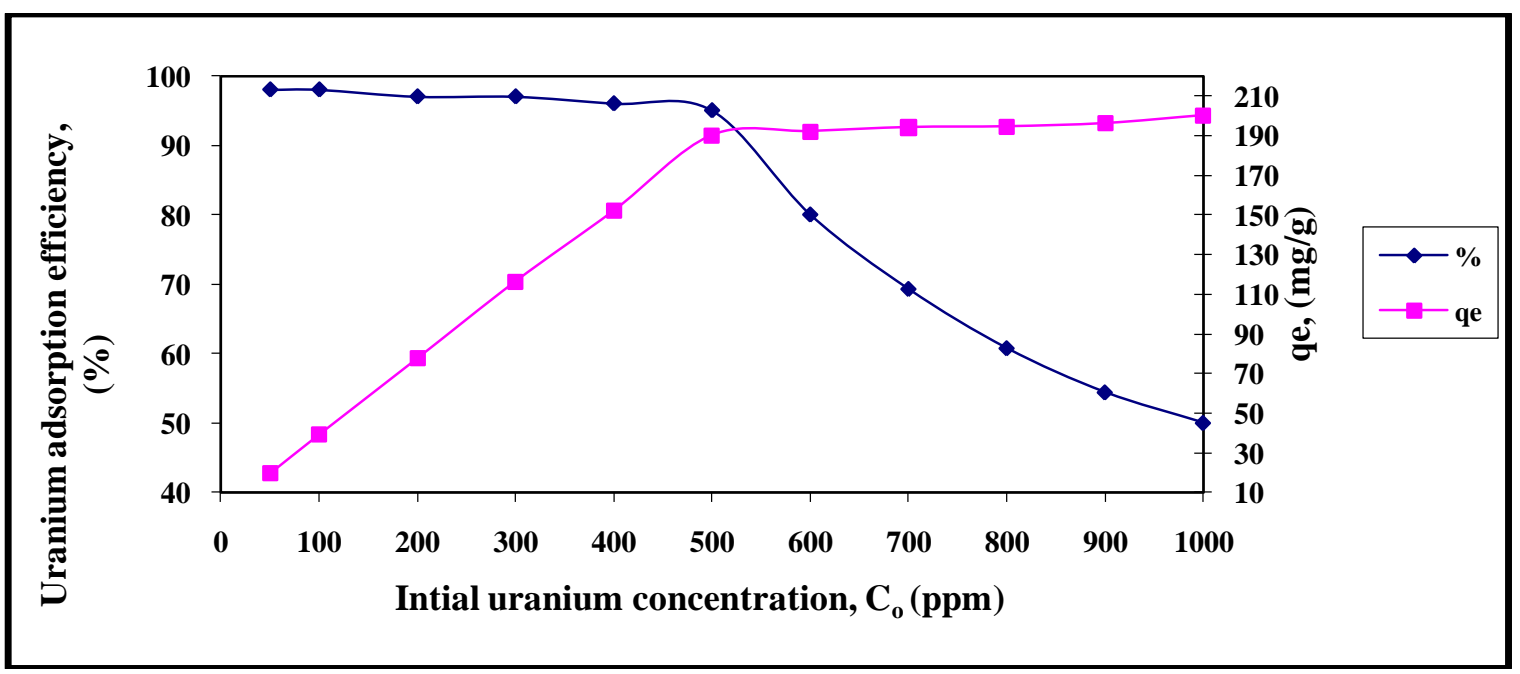

Fig. (7): Effect of initial uranium concentration (ppm) on uranium adsorption efficiency using the prepared (magnetiteDowex 50WX8) composite

Adsorption conditions: $p H$ 4, 30 min. contact time, room temperature and 25 mg composite dose.

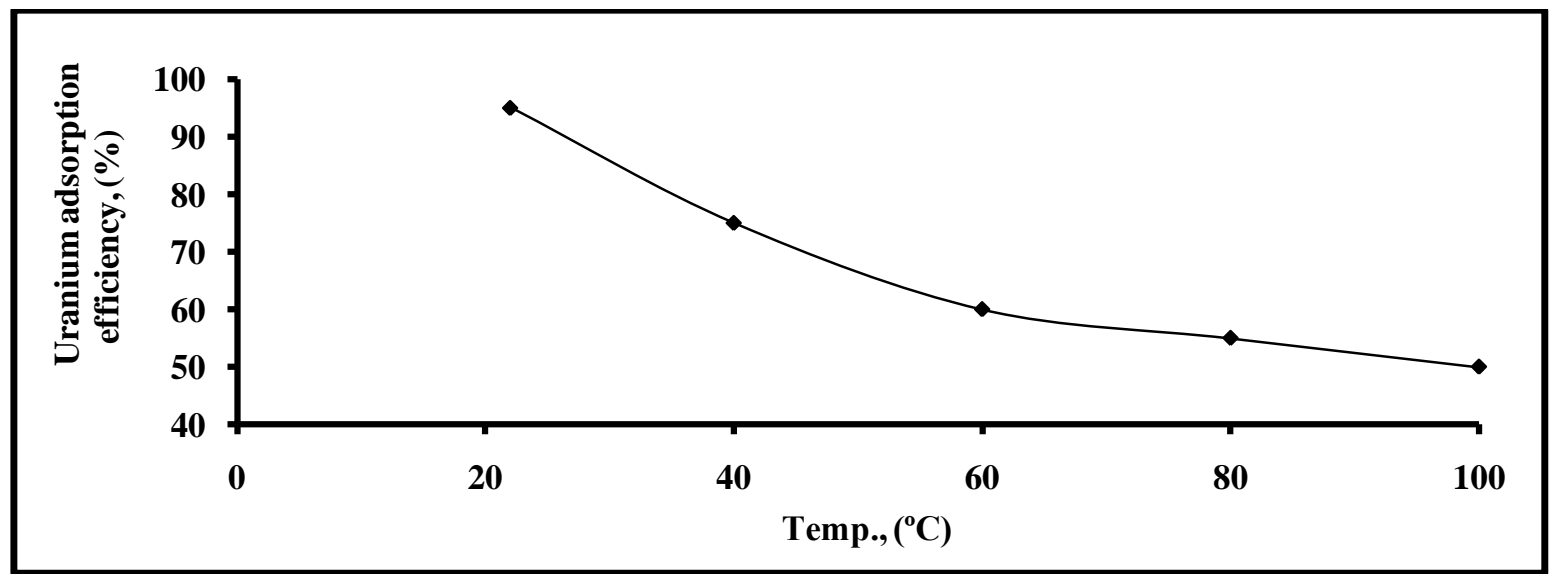

Fig. (8): Effect of temperatures on uranium adsorption efficiency using the prepared (magnetite-Dowex 50WX8) composite Adsorption Conditions: 500 ppm uranium concentration, 30 min. agitation time, pH 4 and 25 mg composite dose.

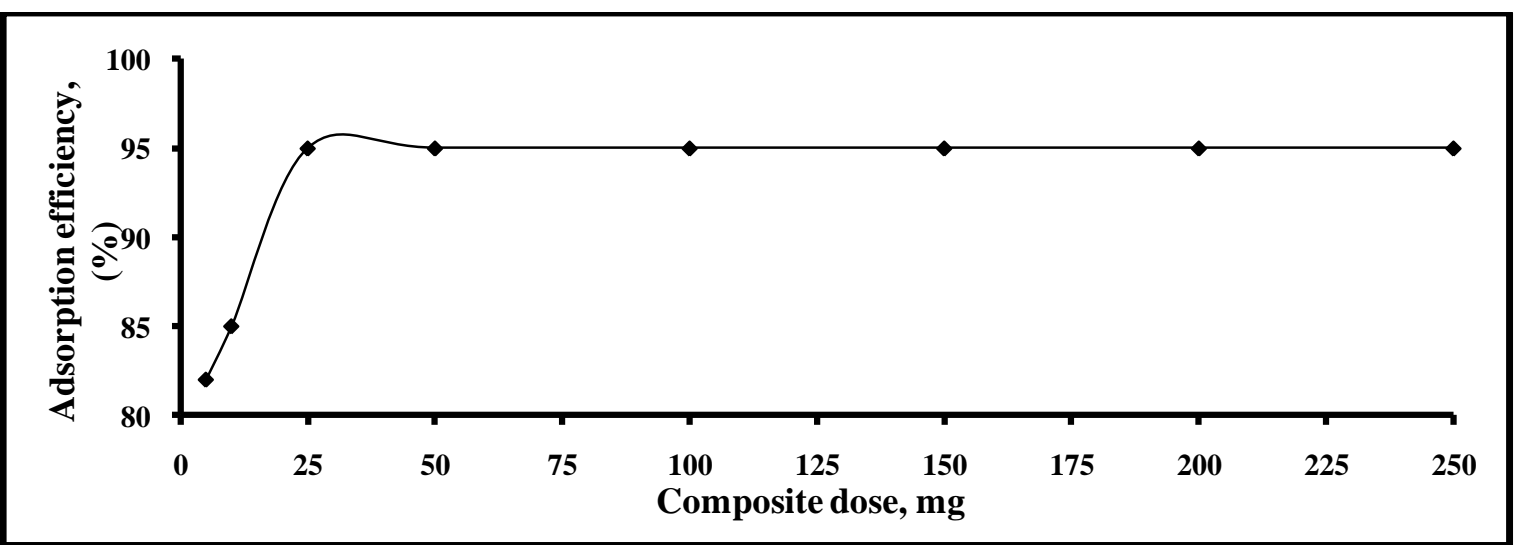

Fig. (9): Effect of composite dose on uranium adsorption efficiency using the prepared (magnetite-Dowex 50 WX8) composite

Adsorption conditions: 500 ppm uranium concentration, 30 min. contact time, room temperature and pH 4. 
Table (3): Effect of eluting agents on uranium loaded onto prepared (magnetite-Dowex 50WX8) composite

\begin{tabular}{cccc}
\hline Concentration, (M) & \multicolumn{3}{c}{ Elution efficiency, \% } \\
\cline { 2 - 4 } & $\mathbf{H N O}_{\mathbf{3}}$ & HCL & $\mathbf{H}_{\mathbf{2}} \mathbf{S O}_{\mathbf{4}}$ \\
\hline $\mathbf{0 . 1 2}$ & 91 & 75 & 76 \\
$\mathbf{0 . 2 5}$ & 99 & 80 & 84 \\
$\mathbf{0 . 5}$ & 99 & 83 & 95 \\
$\mathbf{0 . 7 5}$ & 99 & 83 & 99 \\
$\mathbf{1}$ & 99 & 85 & 99 \\
\hline
\end{tabular}

Adsorption conditions: 500 ppm uranium concentration, 30 min. contact time, room temperature, 25 mg composite dose and $\mathrm{pH} 4$.

Table (4): Effect of nitric acid concentrations (M) on the $\mathrm{Fe}_{2} \mathrm{O}_{3}{ }^{\mathrm{T}}$ dissolution (\%)

\begin{tabular}{|c|c|}
\hline Nitric acid concentration, $(\mathrm{M})$ & $\mathrm{Fe}_{2} \mathrm{O}_{3}{ }^{\mathrm{T}},(\%)$ \\
\hline 0.1 & ------ \\
\hline 0.2 & --------- \\
\hline 0.3 & ------- \\
\hline 0.4 & -------- \\
\hline 0.5 & -------- \\
\hline 0.6 & ------- \\
\hline 0.7 & 0.035 \\
\hline 1 & 0.5 \\
\hline 1.25 & 0.7 \\
\hline 1.5 & 0.85 \\
\hline 1.75 & 1 \\
\hline 2 & 3 \\
\hline 3 & 5 \\
\hline
\end{tabular}




\section{Adsorption equilibrium studies}

Adsorption isotherms were used to characterize the uptake mechanism of uranyl ions by the prepared composite. Uranium ions can be adsorbed by several mechanisms that depend on the density and distribution of adsorption sites, surface area, and affinity of the adsorbent. The mechanism of adsorption also depends on the composition of the aqueous solution $[60,61]$. Sorption experiments were conducted at optimum conditions. $10 \mathrm{ml}$ of solution with initial U conc. of $500 \mathrm{mg} / \mathrm{L}$ are contacted with $25 \mathrm{mg}$ of the prepared composite at a $\mathrm{pH}$ value of 4 and stirred at $200 \mathrm{rpm}$ for 30 minutes at room temperature. Langmuir and Freundlich models were utilized to correlate experimental data. Langmuir model is built on a principle that adsorption mainly occurs as a monolayer surface of the adsorbing material and that adsorption energy is unchanged, while no migration of the adsorbed molecules occurs across the surface [62]. Langmuir model isotherm can be represented mathematically by the following relation:

$$
\frac{C_{e}}{q e}=\frac{1}{b q_{\max }}+\frac{C_{e}}{b q_{\max }}
$$

Where; $\mathrm{Ce}$ is the equilibrium concentration of uranium in the solution $(\mathrm{mg} / \mathrm{L})$, qe is the amount of uranium adsorbed per weight unit of composite at equilibrium time $(\mathrm{mg} / \mathrm{g})$, qmax is the saturated monolayer adsorption capacity $(\mathrm{mg} / \mathrm{g})$ and $\mathrm{b}$ is the Langmuir constant $(\mathrm{L} / \mathrm{mg})$. The linear plots of $\mathrm{C}_{\mathrm{e}} / \mathrm{q}_{\mathrm{e}} \mathrm{Vs} \mathrm{C}_{\mathrm{e}}$ are shown in Fig. (10). As shown from Table (5), the values of maximum capacities $\left(\mathrm{q}_{\max }\right)$ are so close to those of experimental values with correlation coefficient $\mathrm{R}^{2}=0.9997$. The results indicate that the $U$ adsorption process obeys Langmuir isotherm model which implies that the prepared composite is homogeneous in the liquid phase and it is similar to the monolayer adsorption process.

$\mathrm{R}_{\mathrm{L}}$ is a dimensionless constant that stands for a separation factor and is used in the prediction of the degree of spontaneity of the sorption process. The value of that constant is calculated from the assumptions of Langmuir model by the following relation [63]:

$$
\mathrm{R}_{\mathrm{L}}=1 / 1+\mathrm{bC}_{\mathrm{o}}
$$

Where; $\mathrm{b}$ is Langmuir constant and $\mathrm{C}_{\mathrm{o}}$ is the initial concentration of uranium in solution $(\mathrm{ppm})$. If $\mathrm{R}_{\mathrm{L}}=0$, this indicates that the isotherm is irreversible, if $\left(0<\mathrm{R}_{\mathrm{L}}<1\right)$ then, the sorption process is favorable, if $\left(R_{L}=1\right)$ then, the isotherm is linear and if $\left(R_{L}>1\right)$ then, the sorption process is said to be unfavorable. The results show that $\left(0<\mathrm{R}_{\mathrm{L}}<1\right)$ in all cases, indicating that the sorption process is always favorable, according to Langmuir model isotherm.

Freundlich isotherm model assumes that adsorption occurs on a solid surface with heterogenous distribution of energies of the active sites, in a manner that the adsorption is accompanied by interactions between the adsorbed ions [64]. The Freundlich model isotherm can be illustrated mathematically by the following relation:

$$
\ln \mathrm{q}_{\mathrm{e}}=\ln \mathrm{K}_{\mathrm{f}}+\left(\frac{1}{n}\right) \ln \mathrm{C}_{\mathrm{e}}
$$

Where; $\mathrm{C}_{e}$ is the equilibrium concentration of uranium in the solution $(\mathrm{mg} / \mathrm{L}), \mathrm{q}_{\mathrm{e}}$ is the amount of uranium adsorbed per weight unit of composite at equilibrium time $(\mathrm{mg} / \mathrm{g}) . \mathrm{K}_{\mathrm{f}}$ is the adsorption capacity $(\mathrm{mg} / \mathrm{g})$ and $1 / \mathrm{n}(\mathrm{L} / \mathrm{mg})$ is the freundlich constant related to the intensity of adsorption. The Freundlich constants $K_{f}$ and $1 / n$ are calculated from the slope and intercept of the $\log \mathrm{q}_{\mathrm{e}} \mathrm{vs} . \log \mathrm{C}_{\mathrm{e}}$ plots Fig. (11). Adsorption isotherm parameters of Langmuir and Freundlich for adsorption of uranium onto the prepared composite are shown in Table (5). The value of $K_{f}$ is lower than that of the untreated composite at room temperature. From the obtained data, the adsorbent does not obey Freundlich model isotherm.

\section{Sorption kinetics studies}

The study of the kinetic parameters helps to predict the adsorption rate and gives overall information helpful to design and model any extraction process. Both pseudo-first order and pseudosecond order diffusion models were applied to analyze the kinetics of the sorption process of $U$ (VI) onto the prepared composite. Sorption kinetics was studied at uranium concentration of $500 \mathrm{mg} / \mathrm{L}$ at $\mathrm{pH} \mathrm{4,} 200 \mathrm{rpm}$ stirring speed and room temperature. The results were applied to both models. The pseudo first-order model can be mathematically represented by following relation [65]:

$\log \left(\mathrm{q}_{\mathrm{e}}-\mathrm{q}_{\mathrm{t}}\right)=\log \mathrm{q}_{\mathrm{e}}-\left(\mathrm{K}_{1} / 2.303\right) \mathrm{t}$

Where; $\mathrm{q}_{\mathrm{t}}$ and $\mathrm{q}_{\mathrm{e}}$ stand for the quantity of uranyl ions adsorbed by the composite at time $t$ and at 
equilibrium in $(\mathrm{mg} / \mathrm{g})$, respectively. " $\mathrm{k}_{1}$ " is the adsorption rate constant that can be estimated by plotting $\log \left(\mathrm{q}_{\mathrm{e}}-\mathrm{q}_{\mathrm{t}}\right)$ Vs t Fig. (12).

From Table (6), the sorption capacity was determined from the intercept of the plots and was found to be $13.42 \mathrm{mg} / \mathrm{g}$. The correlation coefficient $\mathrm{R}^{2}$ for this model was 0.6943 at $500 \mathrm{mg} / \mathrm{L}$ initial $\mathrm{U}(\mathrm{VI})$ concentration by the prepared (magnetite Dowex 50WX8) composite. It was found that the adsorption processes did not follow pseudo firstorder model.

the results were also applied to pseudo-second order kinetic model in the following form [66]:

$\mathrm{t} / \mathrm{q}_{\mathrm{t}}=1 / \mathrm{k}_{2} \mathrm{q}_{\mathrm{e}}^{2}+\left(1 / \mathrm{q}_{\mathrm{e}}\right) \mathrm{t}$

Where; $\mathrm{k}_{2}$ is the rate constant $(\mathrm{g} / \mathrm{mg} \mathrm{min})$. The straight lines of plots of $t / q_{t}$ against $t$ have a slope $1 / \mathrm{q}_{\mathrm{e}}$ and intercept at $1 / \mathrm{k}_{2} \mathrm{q}^{2} \mathrm{e}$ (Fig. 13). The calculated value of $\mathrm{q}_{\mathrm{e}}$ was $192.30 \mathrm{mg} / \mathrm{g}$ and correlation coefficient $\left(\mathrm{R}^{2}\right)=1$, (Table 6). The results obtained obeyed the pseudo second-order model in a perfect manner at $190 \mathrm{mg} / \mathrm{g}$. Accordingly, the pseudo second order model is suitable to describe the kinetic process of $\mathrm{U}$ (VI) adsorption by the prepared composite. The kinetic process is mainly controlled by the chemi-sorption that involves chemical bonding between uranyl ions and the composite active sites $[67,68]$.

\section{Thermodynamics of uranium adsorption}

The change in energy of molecules accompanying the adsorption process is concerned to the laws of thermodynamics. It helps to understand the appropriate mechanism of the studied adsorption process. Thermodynamic parameters studied involve the change in enthalpy or energy content $(\Delta \mathrm{H})$, change in entropy or randomness $(\Delta \mathrm{S})$ and the change in Gibbs' free energy $(\Delta \mathrm{G})$. These can be mathematically estimated by the following relations [69]:

$$
\begin{aligned}
& \Delta \mathrm{G}=-2.303 \mathrm{RT} \log \mathrm{k}_{\mathrm{d}} \\
& \Delta \mathrm{G}=\Delta \mathrm{H}-\mathrm{T} \Delta \mathrm{S} \\
& \mathrm{k}_{\mathrm{d}}=\left(\mathrm{C}_{\mathrm{o}}-\mathrm{C}_{\mathrm{e}}\right) / \mathrm{C}_{\mathrm{e}} \times \mathrm{V} / \mathrm{m}
\end{aligned}
$$

Where; $K_{d}$ stands for the adsorption equilibrium constant, $\mathrm{R}$ is the universal gas, and $\mathrm{T}$ is temperature in ${ }^{\circ} \mathrm{K}$. On plotting a graph of $\log \mathrm{K}_{\mathrm{d}}$ Vs $1000 / T$, the value $\Delta H$ is estimated from the slope, while the value of $\Delta \mathrm{S}$ is estimated from the intercept Fig. (14).
The thermodynamic parameters estimated are listed in Table (7). The negative values of $\Delta \mathrm{H}$ suggest an exothermic nature of the adsorption of uranium onto the prepared composite. The value of $\Delta \mathrm{G}$ ensures that the reaction is spontaneous.

Uranium (VI) adsorption from the studied leach liquor using the prepared (magnetite-Dowex 50WX8) composite

From the obtained results, it was evident that the prepared (magnetite-Dowex 50WX8) composite is efficient for U(VI) adsorption from solution. A leach liquor of El-Missikat area containing 2000 $\mathrm{mg} / \mathrm{L}$ uranium (VI) was used under the previously determined optimum conditions; $\mathrm{pH} \mathrm{4,} 200 \mathrm{rpm}$ agitation speed for 30 minutes by $4 \mathrm{~L}$ of the leach liquor with 10 grams of the prepared (magnetiteDowex 50WX8) composite. The obtained results showed that uranium (VI) adsorption efficiency reached $95 \%$. The loaded composite was easily stripped from U (VI) ions by $100 \mathrm{ml}$ of $0.25 \mathrm{M}$ $\mathrm{HNO}_{3}$ solution. The eluted uranium content was precipitated using $\mathrm{H}_{2} \mathrm{O}_{2}$ at $\mathrm{pH} 2$. A quantity of $2.5 \mathrm{~g}$ $\left(\mathrm{UO}_{4} .2 \mathrm{H}_{2} \mathrm{O}\right)$ was precipitated. Uranium content in the precipitate was $61 \%$ and the purity of uranium in the obtained uranium concentrate was $86.5 \%$. A comparison of the uptake capacity $(\mathrm{mg} / \mathrm{g})$ of different adsorbents toward uranium is shown in Table (8).

\section{Conclusion}

The prepared (magnetite-Dowex 50WX8) composite used for uranium (VI) adsorption under optimum conditions by the applied batch technique showed a composite capacity of $190 \mathrm{mg} / \mathrm{g}$ at $298 \mathrm{~K}$ using $10 \mathrm{ml}$ of synthetic solution containing 500 ppm of uranium agitated with $25 \mathrm{mg}$ of composite at $\mathrm{pH} \mathrm{4,} 200 \mathrm{rpm}$ agitation speed for 30 minutes. The obtained kinetic data obeyed pseudo secondorder kinetic model that was adopted to represent the studied adsorption mechanism. Langmuir model isotherm was found to be more suitable to explain the present adsorption process. Maximum $\mathrm{U}$ (VI) desorption efficiency was achieved using $0.25 \mathrm{M}$ nitric acid solution. The prepared (magnetite-Dowex 50WX8) composite is higher for uptake capacity than other adsorbents. As a final step, the optimum conditions were applied for $\mathrm{U}$ adsorption from El-Missikat sample, Central Eastern Desert, Egypt after being leached with 95 $\%$ adsorption efficiency. 


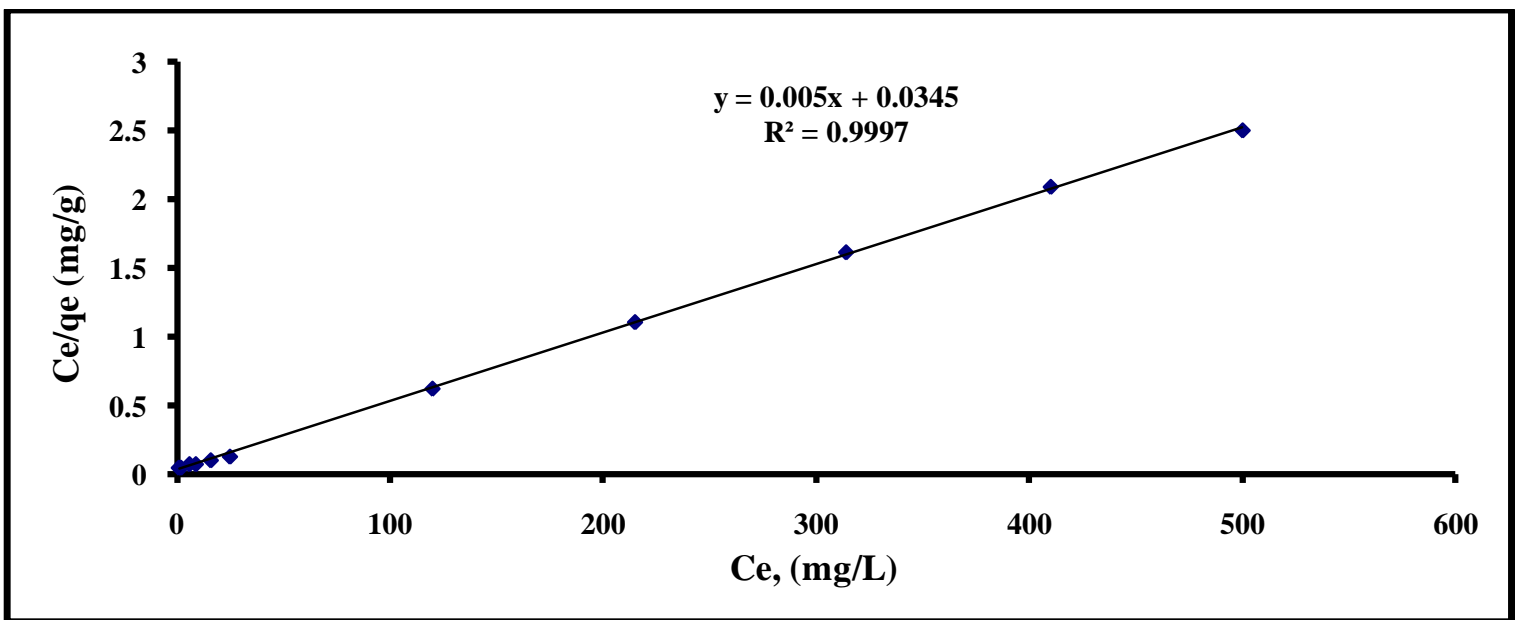

Fig. (10): Langmuir isotherm model of U (VI) adsorption onto the prepared (magnetite-Dowex 50WX8) composite

Table (5): Adsorption isotherm parameters of (Langmuir and Freundlich) for adsorption of uranium onto the prepared (magnetite-Dowex 50WX8) composite

\begin{tabular}{cll}
\hline \multicolumn{1}{c}{ Kinetic models } & \multicolumn{1}{c}{ Parameters } & 298K \\
\hline Langmuir isotherm & Equation & $\mathrm{Y}=0.005 \mathrm{x}+0.0345$ \\
& $\mathrm{q}$ max $(\mathrm{mg} / \mathrm{g})$ & 200 \\
& $\mathrm{~b}(\mathrm{~L} / \mathrm{mg})$ & 0.1449 \\
& $\mathrm{R}^{2}$ & 0.9997 \\
& & $\mathrm{Y}=0.3085 \mathrm{x}+1.592$ \\
Freundlich isotherm & Equation & 39.08 \\
& $\mathrm{k}_{\mathrm{f}}(\mathrm{mg} / \mathrm{g})$ & 0.3085 \\
& $1 / \mathrm{n}(\mathrm{mg} \min / \mathrm{g})$ & 0.7594 \\
& $\mathrm{R}^{2}$ & \\
\hline
\end{tabular}

Adsorption conditions: 500 ppm uranium concentration, 30 min. contact time, room temperature, $25 \mathrm{mg}$ composite dose and $\mathrm{pH} 4$.

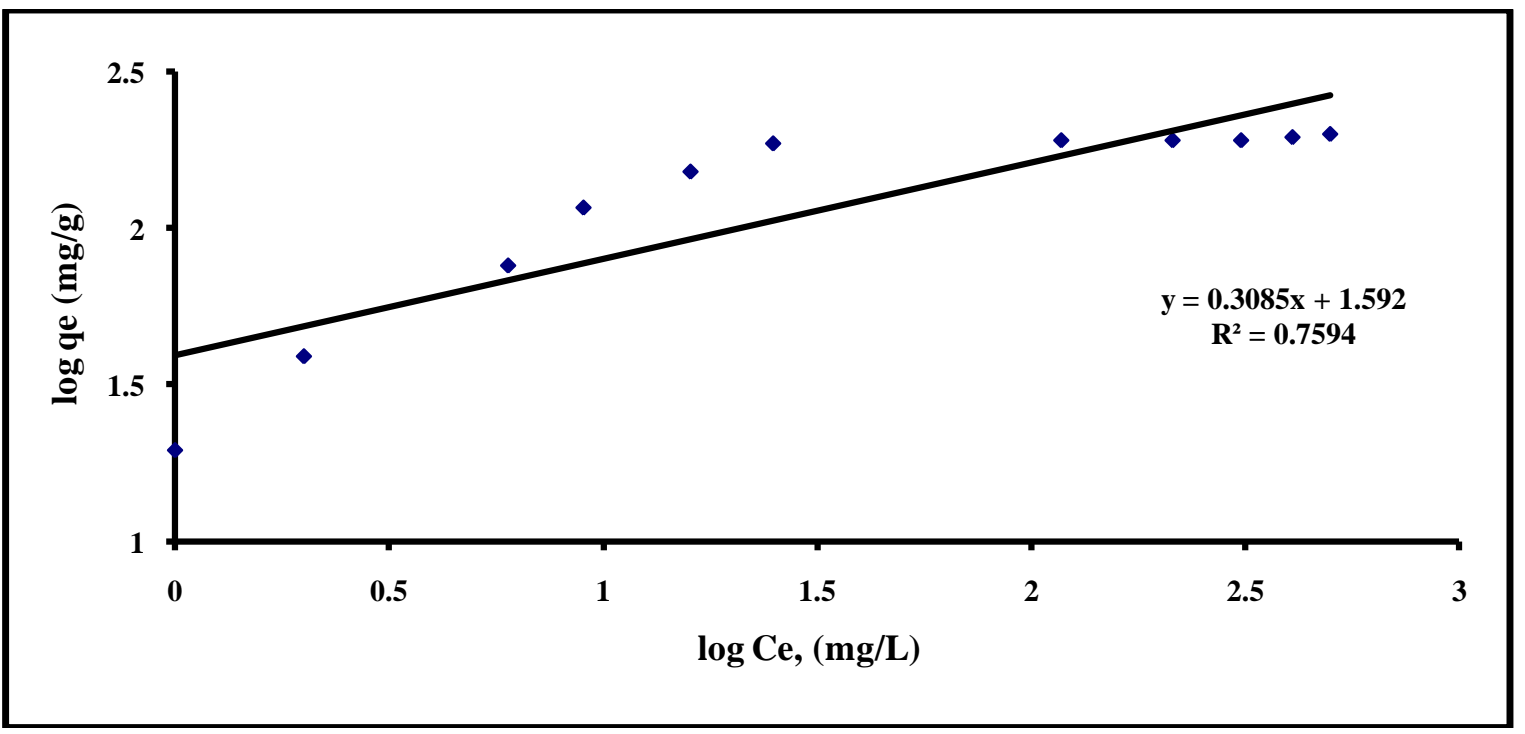

Fig. (11): Freundlich isotherm model of U (VI) adsorption onto the prepared (magnetite- Dowex 50WX8) composite 


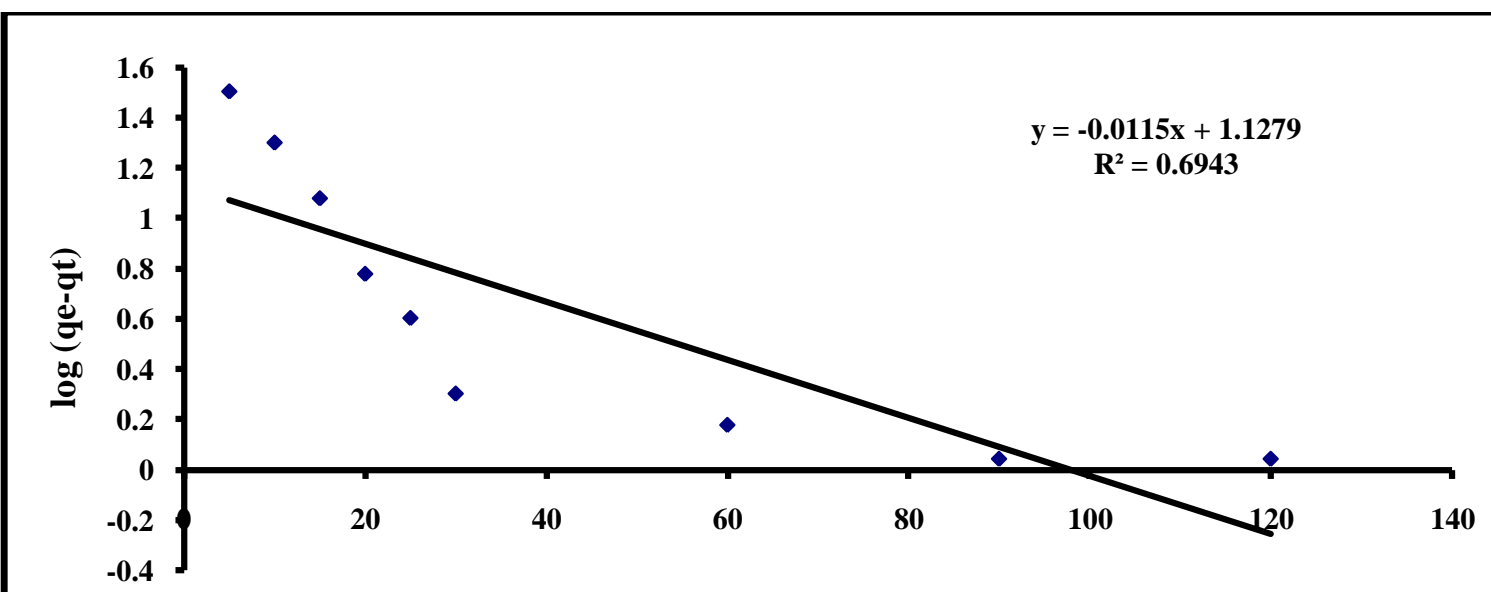

Time, (min.)

Fig. (12): Pseudo first order model of U (VI) onto the prepared (magnetite-Dowex 50WX8) composite

Table (6): Kinetic model parameters applied to uranium onto the prepared (magnetite- Dowex 50WX8) composite

\begin{tabular}{|c|c|c|}
\hline Kinetic models & Parameters & \\
\hline \multirow[t]{3}{*}{ First order parameter } & $\overline{\mathrm{q}_{\mathrm{e}}(\mathrm{mg} / \mathrm{g})}$ & $\overline{13.42}$ \\
\hline & $\mathrm{K}_{1}\left(\mathrm{~min}^{-1}\right)$ & 0.026 \\
\hline & $\mathrm{R}^{2}$ & 0.6943 \\
\hline \multirow[t]{3}{*}{ Second order parameter } & $\mathrm{q}_{\mathrm{e}}(\mathrm{mg} / \mathrm{g})$ & 192.30 \\
\hline & $\mathrm{K}_{2}(\mathrm{~g} / \mathrm{mg} \cdot \mathrm{min})$ & 0.00614 \\
\hline & & \\
\hline
\end{tabular}

Adsorption conditions: 500 ppm uranium concentration, 30 min. contact time, room temperature, $25 \mathrm{mg}$ composite dose and $\mathrm{pH} 4$.

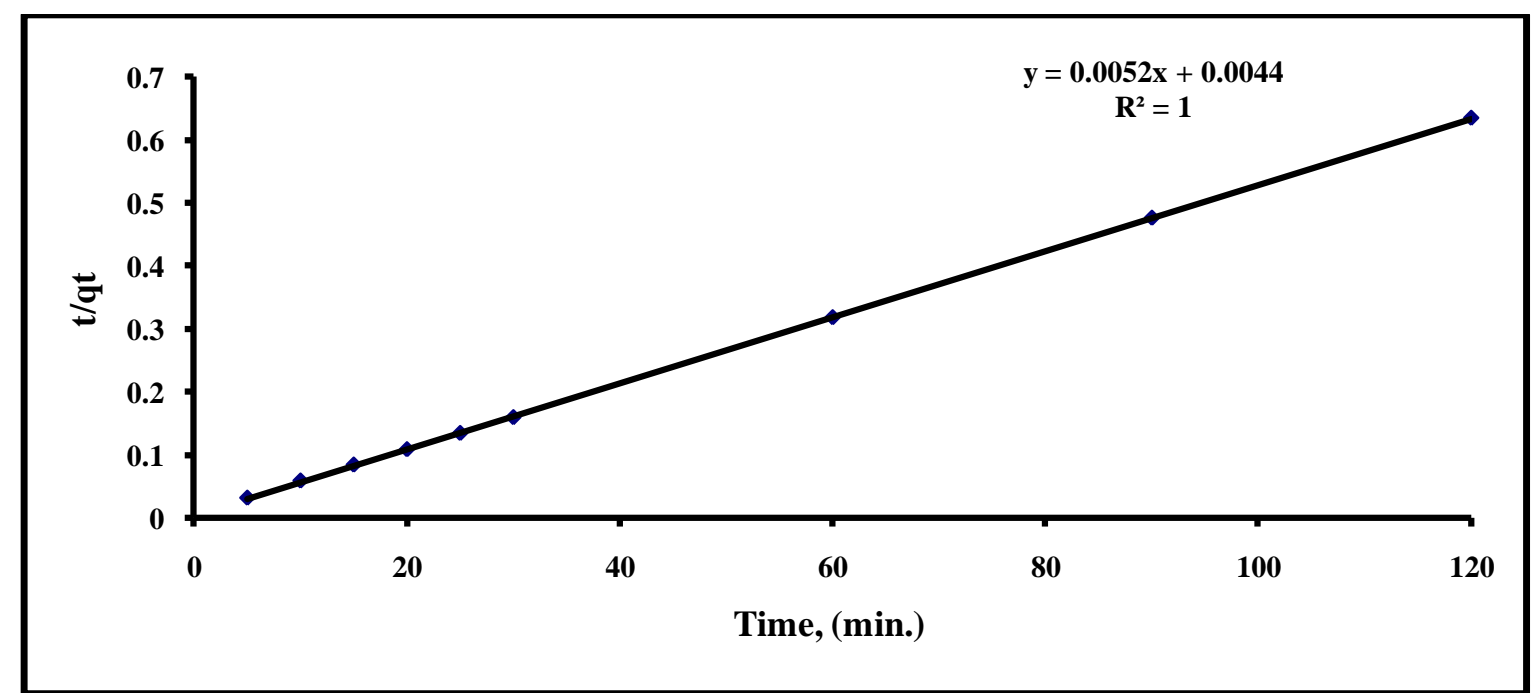

Fig. (13): Pseudo second order model of U (VI) onto the prepared (magnetite-Dowex 50WX8) composite 


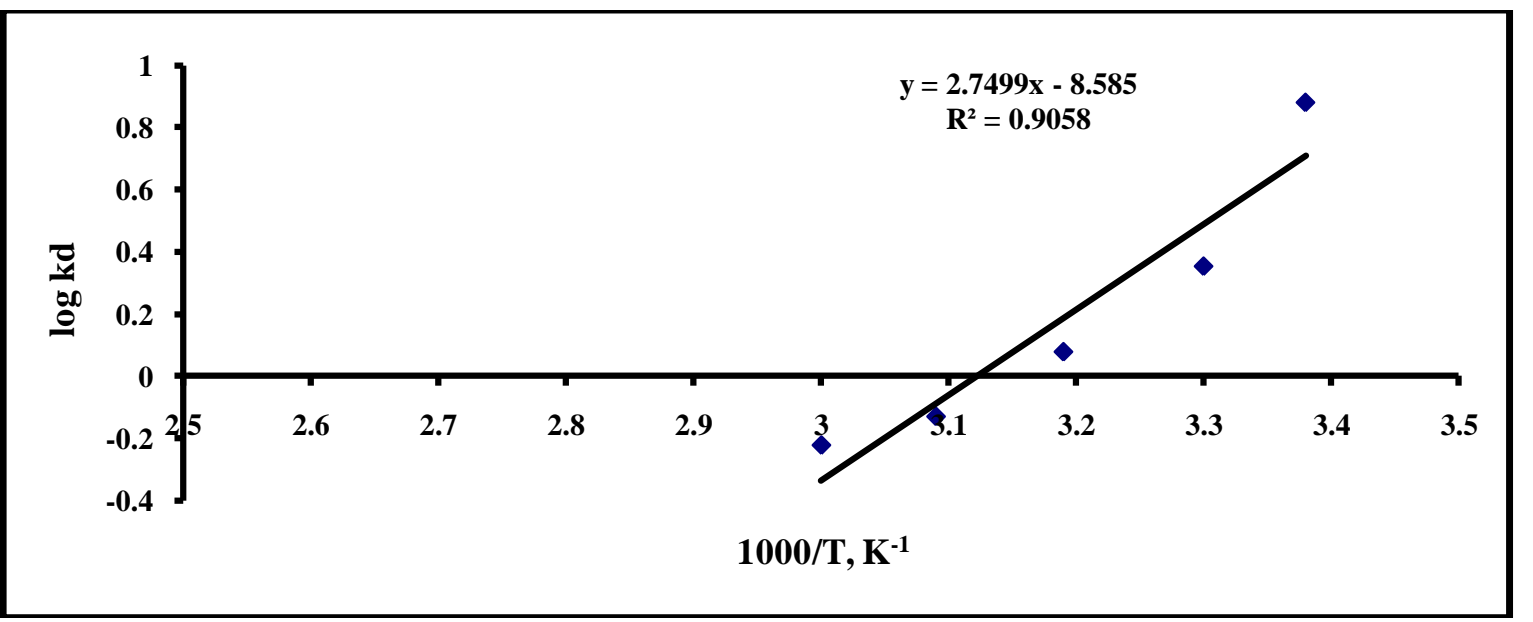

Fig. (14): A plot of $\log K_{d}$ against 1000/T for uranium adsorption onto the prepared (magnetite-Dowex 50WX8) composite

Table (7): Thermodynamic parameters for the uranium adsorption onto the prepared (magnetite-Dowex 50WX8) composite

\begin{tabular}{ccccc}
\hline Temperatures, $\left({ }^{\mathbf{o}} \mathbf{C}\right)$ & Temperatures, $\left({ }^{\mathbf{}} \mathbf{K}\right)$ & $\begin{array}{c}\mathbf{\Delta H}, \\
(\mathbf{K J} / \mathbf{m o l})\end{array}$ & $\begin{array}{c}\mathbf{\Delta G}, \\
(\mathbf{K J} / \mathbf{m o l})\end{array}$ & $\begin{array}{c}\mathbf{\Delta S}, \\
\left(\mathbf{K J} / \mathbf{m o l} . \mathbf{K}^{\mathbf{1}}\right)\end{array}$ \\
\hline $\mathbf{2 2}$ & $\mathbf{2 9 5}$ & & -4.97 & -0.1616 \\
$\mathbf{3 0}$ & $\mathbf{3 0 3}$ & -52.65 & -2.05 & -0.1669 \\
$\mathbf{4 0}$ & $\mathbf{3 1 3}$ & & -0.474 & -0.1666 \\
$\mathbf{5 0}$ & $\mathbf{3 2 3}$ & & 0.797 & -0.1654 \\
$\mathbf{6 0}$ & $\mathbf{3 3 3}$ & & 1.409 & -0.1623 \\
\hline
\end{tabular}

Table (8): A comparison of the uptake capacity (mg/g) of different adsorbents toward uranium

\begin{tabular}{lcc}
\hline \multicolumn{1}{c}{ Adsorbent } & $\begin{array}{c}\text { Capacity, } \\
(\mathbf{m g} / \mathbf{g})\end{array}$ & References \\
\hline Dowex 1X8 & 89 & {$[30]$} \\
Ambersep 920U SO 4 & 58 & {$[35]$} \\
Dowex 1X-8 & 69 & {$[70]$} \\
Dowex 1X-8 & 73.6 & {$[71]$} \\
Dowex 1X-8 & 134.86 & {$[72]$} \\
Dowex 1X- 8 & 100 & {$[73]$} \\
Dowex 2IK sulphate & 95 & {$[74]$} \\
Dowex 1X- 8 & 84 & {$[75]$} \\
Amberlite XAD-4 functionalized with succinic acid & 90 & {$[76]$} \\
Purolite S985, & 120 & {$[77]$} \\
DOWEX 50 WX8 & 110 & {$[78]$} \\
Lewatit MonoPlus TP 214 & 152.2 & {$[79]$} \\
Dowex M4195 & 78 & {$[80]$} \\
Dowex 1X & 90 & {$[81]$} \\
Amine-impregnated cellulose (AIC) & 56.5 & {$[82]$} \\
Dowex MSA-2 & 108.93 & {$[83]$} \\
(ZMPP-TBP) & 196.08 & {$[84]$} \\
polyvinyl alcohol functionalized with amidoxime & 42.84 & {$[85]$} \\
Purolite A500 & 90 & {$[86]$} \\
Present work & $\mathbf{2 0 0}$ & L.A.Yousef \\
\hline
\end{tabular}




\section{Recommendations}

To keep the stability of the prepared (magnetiteDowex 50WX8) composite and prevent iron dissolution, nitric acid concentration must not exceed $0.6 \mathrm{M} \mathrm{HNO}_{3}$.

\section{Acknowledgements}

The Author would like to express thanks and gratitude to Prof. Dr. Sofia Y. Afifi; Professor of geochemistry and Prof. Dr. Tarek M.M. Ibrahim; professor of geology, Nuclear Materials Authority (NMA), for their help, support, fruitful discussions and continuous follow up of this work. Their valuable advice along the experimental work, and continuous unlimited encouragement till the final presentation of this work are highly appreciated.

\section{References}

1-J.Choi, J. Y. Lee and J. S. Yang ; Journal of Hazardous Materials; 15, 157 (2009).

2-R. T. Anderson, H. A.Vrionis, I. Ortiz-Bernad, C. T. Resch, P. E. Long and R. Dayvault; Applied and Environmental Micrbiology; 69, 5884 (2003).

3-G. P. Curtis, J. A. Davis and D. L. Naftz; Water Resources Research; 42, 4404 (2006).

4-S.Yabusaki, Y.Fang and S. R.Waichler; Water Resources Research; 44, 12403(2008).

5-A.Mellah, S. Chegrouche and M. Barkat; Hydromtallurgy; 85, 163 (2007).

6-C.Zhang, C. J. Dodge, S. V.Malhotra and A. J. Francis; Bioresource Technology; 136, 752 (2013).

7-F. A. Aydin and M. Soylak; Talanta; 73, 134 (2007).

8-R. J. Reeder, M. Nugent, C. D.Tait, D. E. Morris, S. M. Heald and K. M.Beck; Geochimica and Cosmochimica Acta; 65, 3491(2001).

9-Y. K. Agrawl, P. Shrivatav and S. K. Mnom; Separation and Purification Technology; 20, 177 (2000).

10-J. E.Quinn, D.,Wilkins and K. H. Soldenhoff; Hydrometallurgy; 134, 74 (2013).

11-Z. Zhu, Y.Pranolo and C. Y. Cheng; Minerals Engineering; 89, 77 (2016).

12-M. L. Dietz, H. E. Philip, L. R.Sajdak and R. Chiarizia; Talanta, 54, 1173 (2001).

13-T. R. Prasada, P. Metilde and J. M. Gladis; Talanta; 68, 1047 (2006)

14-B. Gu, Y. Ku and G. M. Brown; Environmental Science \& Technology; 39, 901 (2005).

15-V. A. Pulhani, S. Dafauti and A. G. Hegde; Radioanalytical and Nuclear Chemistry; 294, 299 (2012).

16-M. Solgy, M.Taghizadeh and D. Ghoddocynejad; Annals of Nuclear energy; 75, 132 (2015).

17-J. Bockris; "Electrochemistry of cleaner environments", New York: Plenum Press, 296 (1972).
18-F. Barbette, F. Rascalou, H.Chollet, J. L.Bahouhot, F. Denat and R. Guilard; Analytica Chimica Acta; 502, 179 (2004).

19-A.R.Keshtkar, M. Irani and M.A. Moosavian; Radioanalytical and Nulear Chemistry; 295, 563 (2013).

20-Q. Song, L. Ma, J. Liu, C. Bai, J. Geng, and H. Wang; Journal of Colloid and Interface Science; 386, 291 (2012).

21-A. M. Yousif, A. H. El-Afandy, G. M. AbdelWahab, A. E. Mubark and I. A. Ibrahim; Radioanalytical and Nuclear Chemistry; 303,1821(2015).

22-W. Zou and L. Zhao; Radioanalytical and Nuclear Chemistry; 292, 585 (2012).

23-23- J. Drozdzaka, M. Leermakersa, Y. Gaoa, M. Elskensa, V. Phrommavanhb and M. Descostesb; Analytical Chimica Acta; 913, 94 (2016).

24-J.Shena and A. Schferb; Chemosphere; 117, 679 (2014)

25-T. Sreenivas and K. C. Rajan; Separation and purification Technology; 112, 54 (2013).

26-A. S. Saini and J. S. Melo; Environmetal Radioactivity, 142, 29 (2015).

27-Y. G. Ko, J. M. Lim, G. S. Choi, K. H. Chung and M. J. Kang; Physicochemical and Engineering Aspects; 487, 121 (2015).

28-A. Bhatnagar, E. Kumar and M. Sillanp; Chemical Engineering; 171, 811 (2011).

29-M. Rafatullah, O. Sulaiman, R. Hashim and A. Ahmad; Hazardous Materials; 177, 70 (2010).

30-F. M. Guzman; Chemistry and Chemical Engineering; 10, 90 (2016).

31-M. N. Kouraim, M. E. Sheta and M. M. Abd Elaal; European Journal of Chemistry; 5, 446 (2014).

32-F. Semnani, Z. Asadi, M.Samadfam and H. Sepehrian; Annals of Nuclear Energy; 48, 21 (2012).

33-A.Kilislioglu and B.Bilgin; Applied Radiation and Isotopes; 58, 155 (2003).

34-A.Rahmati, A. Ghaemi and M. Samadfam; Annals of Nuclear Energy; 39, 42 (2012).

35-M.F. Cheira, B.M. Atia and M.N. Kouraim; Radiation Reserch and applied Sciences; 10, 307 (2017).

36-Y.Chen, B. Pan, H. Li, W. Zhang, L. Lv. and J. Wu; Environ. Sci. Techno.; 44, 3508 (2010).

37-L.Wan, Y.Wang and S. Qian; Appl. Polym. Sci.; 84, 29 (2002).

38-A.J.Varma, S.V.Deshpande and J.F.Kennedy; Carbohydr. Polym.; 55 , 77(2004).

39-V.Yargeau and F. Zeman; Environmental; 22, 390 (2012).

40-D.D. Ratnayaka, M.J. Brandt and K.M. Johnson; Water Supply; 30, 315 (2009).

41 - A. Funes, J.Vicente, L. Cruz-Pizarro and I.Vicente; Water Res.; 53, 110 (2014).

42-A.M.G.C. Dias, A., Hussain, A.S. Marcos and A.C.A. Roque; Biotechnol Adv.; 29, 142 (2011). 
43-V. Gupta and I. Ali; Environmental Water; 45, 29 (2013 a).

44-V. Gupta and I. Ali; Environmental Water; 22, 93 (2013 a).

45-R. Ianos, C. Pacurariu and G. Mihoc; J. RSC advances; 4, 62621(2014).

46-A. A. Atia, A. M. Donia, and A. E. Shahin; Sep. Purif. Technol.; 46, 208 (2005).

47-N. M. T. El Hazek; "Studies on the leachability and uranium concentration of El-Atshan and comparable ores in relation to mineralogical composition", M. Sc. Thesis, Ein Shams Univ.,Egypt, 165 (1965).

48-T. E. Amer, T. M. Ibrahim and S. A. Omar; The fourth international conference on the Geology of Africa, Assiut, Egypt, 2-5 Nov., 225 (2005).

49-M.R. Lasheen, I. Y. El-Sherif, S.T. El-Wakeel, D.Y. Sabry and M.F. El-Shahat; J. of materials and environmental Sciences; 8, 503 (2017).

50-J.Dong and Y. Ozaki; Macromolecules; 30, 286 (1997).

51-A.Warshawsky, J.A. Marinsky and Y. Marcus; "Ion Exchange and Solvent Extraction", Marcel-Dekker Inc., New York, 229 (1981).

52-K.J. Mathew, B. Mason, M. E. Morales and U. I. Narayann; Journal of Radioanalytical and Nuclear Chemistry; 282, 939 (2009).

53-Z. Marczenko and M. Balcerzak; "Separation, preconcentration and spectro-photometry in inorganic analysis"; Amesterdam, Netherland: Elsevier Science B.V., 200 (2000).

54-L. Shapiro and W. W. Brannock; U.S Geological Survey Bulletin; 114, 43 (1962).

55-K. Govindaraju, C. Mevelle and C. Chouard; Anal. Chem.; 48, 1325 (1976).

56-S. A. M. Omar, S. M. Abdallah, A. E. Omran, M. Z. Abdel Monsef, K.Abu El-Wafa and F. Z. Yossef; Gabal El Missikat Development Project; Internal Report, 72 (2013).

57-N. Ferrah, O. Abderrahim, M. A. Didi and D.Villemin; Journal of Radioanalytical and Nulear Chemistry; 289, 721(2011).

58-W.S. Wan Ngah, C.S. Endud and R. Mayanar; React. Funct. Polym.; 50, 181(2002).

59-M. Tsezos and B.Volesky; Biotechnol. Bioeng.; 24 , 385 (1982)

60-M. Chabani, A. Amrane and A. Bensmaili; Chemical Engineering; 125, 111(2006).

61-T. W.Weber and R. K. Chakraborti; American Institute of Chemical Engineers ; 20, 228 (1974).

62-I. Langmuir; American Chemical Society; 40, 1361(1918).

63-D. Humelnicu, G. Drochioiu, M. I. Sturza, A. Cecal and K. Popa; Journal of Radioanalytical and Nulear Chemistry; 270, 637 (2006).

64-H. Freundlich; Physical and Chemical Society; 40, 1361 (1906).
65-S.Lagergren; Science Chem.; 24, 39(1898).

66-X. Zhang, C. Jiao, J.Wang, Q. Liu, R. Li and P.Yang; Chemical Engineering journal; 198, 412 (2012).

67-F. C.Wu, R. L. Tseng and R. S. Juang; Hazardous Materials; 81, 167 (2001).

68-L. Ding, H. P. Deng, C.Wu and X. Han; Chemical Engineering Journal, 181, 360 (2012).

69-G. Bayramoglu and M.Y. Arica; Water, Air and Soil Pollution; 221, 391 (2011).

70-70- A.J. Britz and F.L.D. Cloete ; Hydrometallurgy; 25, 213 (2015).

71-71- M.T. Crespo, M.L. Acena and E. Garcia; The Science of the total Environmental ; 70, 253 (2016).

72-72- J. Korkisch and G. E. Janauer ; Hydrometallurgy ; 9, 957 (2015).

73-73- T. Kiriyama; Analytica Cirimicvt Acts.; 7 1, 315 (2014).

74-74- S . M. Khopkar and K. D. Anil; Analytica Chimica Acta; 23, 147 (2009).

75-75- H. Hamaguchi, I. Hikawa and R. Kurda; Hromatography; 8, 556 (2014).

76-76- P. Metilda, K. Sanghamitra, J. M. Gladis, G.R.K. Naidu and T. P. Rao; Talanta; 65, 192 (2015).

77-77- T.M. James, A. M. D. Ogden, R. I. Foster, N. Syna, K. H. Soldenhd and C. A. Sharrad; Chemical Engineering Journal ; 354, 633 (2018).

78-78- O. Alhassanieh , A. Abdul-Hadi , M. Ghafar and A. Aba; Applied Radiation and Isotopes; 51, 493 (2012).

79-79- S. B. Choi, S.W.Won and Y.S. Yun; Chemical Engineering Journal; 214, 78 (2013).

80-80- M. D. Ogden, E. M. Moon, A. Wilson and S. E. Pepper; Chemical Engineering Journal; 317, 80 (2017).

81-81- B. Danko, R.S. Dybczyński,, Z. Samczyński, D. Gajda, I.H. Koniecko, G.K. Kołtuniewicz, E. Chajduk, and K. Kulisa ; Hydrometallurgy; 62(3), 213 (2017).

82-82- A. H. Orabi, E. M. El-Sheikh, W. H. Saleh, A. O. Youssef, M. Y. El-Kady and Z. M. Shalaby; Journal of Radiation Research and Applied Sciences; 9, 193 (2016).

83-83- A.C.Q. Ladeira and L.C. Sicupira; International Conference of Environmental Science and Technology; Athens, Greece, 5-7 September (2013).

84-84- S. Zhou, B. Chen, Y.Y.Gad, J.C.X. Lii, Z. Qin, J. Bai and P. P. Nay; Science China Chemistry; 56, 1516 (2013).

85-85- C. F. Ting, H.U. Sheng, X. Jie, and W. X. Lin; Science China Chemistry; 56, 1495 (2013).

86-86-V. Stucker, J. Ranville, M. Newman, A. Peacock, J. Cho and K. Hatfield; Water Research; 45, 4866 (2011) 